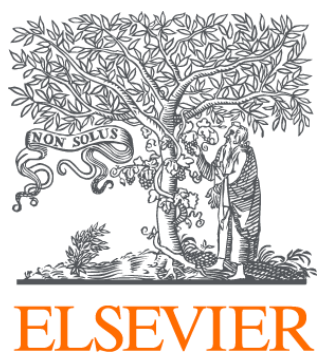

Since January 2020 Elsevier has created a COVID-19 resource centre with free information in English and Mandarin on the novel coronavirus COVID-

19. The COVID-19 resource centre is hosted on Elsevier Connect, the company's public news and information website.

Elsevier hereby grants permission to make all its COVID-19-related research that is available on the COVID-19 resource centre - including this research content - immediately available in PubMed Central and other publicly funded repositories, such as the WHO COVID database with rights for unrestricted research re-use and analyses in any form or by any means with acknowledgement of the original source. These permissions are granted for free by Elsevier for as long as the COVID-19 resource centre remains active. 


\title{
COVID-19 and bailout policy: The case of Virgin Australia
}

\author{
Yahua Zhang ${ }^{\text {a,*, }}$ Anming Zhang ${ }^{\mathrm{b}}$ \\ ${ }^{a}$ School of Business, University of Southern Queensland, Toowoomba, Queensland, Australia \\ ${ }^{\mathrm{b}}$ Sauder School of Business, University of British Columbia, Vancouver, BC, Canada
}

\section{A R T I C L E I N F O}

\section{Keywords:}

COVID-19 pandemic

Airline bailouts

Empty core

Qantas

Virgin Australia

\begin{abstract}
A B S T R A C T
The impact of COVID-19 on air transport is unprecedented and some well-known airline brands may disappear as a result. Governments around the world have responded swiftly to cushion the financial impact by offering direct wage subsidies, tax relief, loans, etc. This paper explores the government's appropriate responses to failing airlines' bailout request by examining the case of Virgin Australia. Following the bailout policy principles established in the literature, we suggest that bankruptcy protection should be considered as the first solution to a failing carrier. A bailout decision should be guided by a set of principles and procedures, which should not be taken lightly. Our analysis also shows that the government cannot take a hands-off approach in the absence of private lenders and investors, as the costs to consumers and regional residents would be huge if the carrier could not get through the COVID-19 pandemic. A minimum level of assistance with conditions might be needed to maintain market competition.
\end{abstract}

\section{Introduction}

Since the 1980s, as with many other industries, publicly owned and operated national flag carriers have been fully or partially privatised across the world. Backx et al. (2002) note this was driven by the motivations of enhancing airline financial performance and operating efficiency. Since air transport has been deregulated, people believe that market forces have overall been working very well and that governments should stay out of commercial activities, unless the market has failed and there are no other options except for government intervention (Zhang et al., 2012). Even in the case of providing air services to remote communities, a competitive tendering procedure is followed to make more efficient use of public funds (Button, 2017). It has been widely agreed that a higher level of private and foreign ownership provides management with greater incentives to cut costs and enhance incentives (Zhang and Findlay, 2010; Tleane, 2020). Empirical evidence has shown that private carriers perform better than state-owned carriers (Backx et al., 2002; Yu et al., 2019).

However, air transport is highly cyclical and seasonal, and airline revenues can fluctuate widely in a business cycle (Zhang and Zhang, 2018). In fact, airlines are a service industry that requires significant capital investment, and shareholders do not normally receive a fair reward from investing in this industry (Pearce, 2018). Intermittent exogenous shocks such as terrorism attacks and pandemic diseases can easily kill an airline due to the low profit margin and high fixed costs associated with its operation. Instability seems inherent in this industry, resulting in frequent calls for intervention, or even reregulation. The term "bailout" is frequently heard during these shocks and other economic crises, particularly in the 2008-2009 global financial crisis and the current COVID-19 pandemic crisis.

The COVID-19 pandemic is considered as one of the biggest social and economic shock since the Great Depression. As governments started to impose restrictions concerning human mobility and air travel, ${ }^{1}$ airlines saw their demand melt down almost immediately, and were forced into cancelling flights and grounding fleets (e.g., Abate et al., 2020; Sun et al., 2020). For instance, United Airlines announced on March 17, 2020 a $60 \%$ reduction in its April schedule $-42 \%$ in the US and Canada flights and $85 \%$ in international flights. On the same day, Qantas Group (Qantas and Jetstar) announced that their international capacity would be cut by $90 \%$ and domestic by $60 \%$ starting from the end of March 2020.

With revenues plummeting and the financial situation deteriorating, many governments have announced financial relief packages for airlines. For instance, the United States (US) has implemented the

\footnotetext{
* Corresponding author.

E-mail addresses: shane.zhang@usq.edu.au (Y. Zhang), anming.zhang@sauder.ubc.ca (A. Zhang).

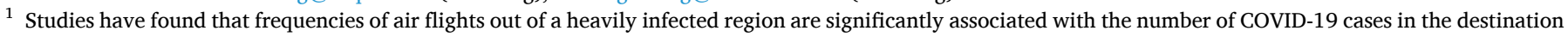
regions (e.g., Christidis and Christodoulou, 2020; Gilbert et al., 2020; Pullano et al., 2020; Zhang et al., 2020).
} 
Coronavirus Aid, Relief, and Economic Security Act (CARES) stimulus package, which earmarks US $\$ 50$ billion in loans and salary support for its passenger airlines. These relief programs can, among others, help airlines address their short-term liquidity issues. In Australia, the federal government's support includes a $\$ 715$ million package waiving fuel excise and government charges backdated to February $1,2020 .^{2} \mathrm{~A}$ further $\$ 198$ million was set aside to ensure the continued operation of essential flights into regional communities and \$100 million direct financial support for the smaller regional airlines. The JobKeeper wage subsidy program ( $\$ 1500$ biweekly) was also available to businesses in the airline industry. However, like the US case the waiving of airways fees and charges can only be realised when flights are actually taking place. Hence, the assistance is not quite meaningful when almost all the flights are grounded (Tisdall and Zhang, 2020).

Amid the escalation of the COVID-19 pandemic, Australia shut its borders and then Australian states shut theirs in late March 2020. Virgin Australia, the second largest carrier in Australia, was the first casualty of the travel restrictions. This debt-laden carrier quickly ran out of cash reserves and had to put a request for a $\$ 1.4$ billion bailout loan, which was rejected by the Australian federal government. Interestingly, Qantas openly expressed its opposition to any government assistance for Virgin Australia, claiming that this was time for the fittest to survive. Qantas did not need a government bailout this time, but it insisted that if there were any government assistance, it should be proportional: as Qantas's revenue was three times higher than Virgin's, it should have a $\$ 4.2$ billion loan to level the playing field. This obviously complicated the government's decision on whether or not to help. Eventually, the federal government refused to bail out Virgin Australia. The issue whether the government should give a hand to Virgin Australia or have a stake in an airline in financial distress has caught the attention of the general public in Australia and sparked much debate. This paper will document and examine this case with a set of bailout principles and conditions developed in the literature in a bid to show the significance of developing a bailout policy analytical framework for decision makers. In the next section, we draw literature on the debates on bailouts and government intervention in the air transport sector, followed by the methodology. The case of Virgin Australia is presented in section 4. Section 5 concludes.

\section{Literature review: the debates on bailouts and government intervention}

It is generally believed that unless there is market failure, the government should be refrained from adopting any public policy towards bailouts (Block, 1992). However, the notion of "too-big-to-fail" has led to taxpayer money being used to rescue some large financial firms that were considered to pose a huge risk to the entire economy upon failure (Block, 2010). The taxpayer money was also used to rescue non-financial firms, such as the financial aid provided to the airline industry to stabilise and sustain air transport post " $9 / 11$ ". Although widely used, there is no strict definition for the term "bailout". In most cases, this term refers to the government assistance offered to a private firm or private industry. However, Block (1992) distinguishes bailouts and government general subsidies. The former aims to prevent the failure of a private enterprise or industry, while the latter intends to encourage a particular desired behaviour or favoured activity. Therefore, Block (1992, p.960) defines "bailout" as "a form of government assistance or intervention specifically designed or intended to assist enterprises facing financial distress and to prevent enterprise failure". Similarly, Posner and Casey (2015, p. 487) define a bailout as "an ex post government transfer (a loan, cash, or other consideration) to an agent or group of agents to provide capital that is otherwise unavailable because of liquidity constraints".

\footnotetext{
${ }^{2}$ \$ means Australian dollar unless otherwise specified.
}

There are good reasons for bailouts. Fu et al. (2010) and Zhang (2012) pointed out that the aviation sector imposes significant positive externalities to other industries. For example, Button et al. (1999) found that the presence of a hub airport could greatly increase high-tech employment by an average of 12,000 jobs in the airport catchment. Clearly a private investor is not likely to capture the full value from his/her investment into an airline. Therefore, air transport has been long regarded as a critical sector to the normal operation of an economy. In addition, although many bailout programs require large government expenditures, some bailout forms such as loan guarantee programs involve little or no government revenue (Block, 1992). There is also the case where the government loans to the failing firm could be repaid in full at a later time. However, Azgad-Tromer (2017) pointed out that the positive externality argument may lead private investors to assume that taxpayers will most likely bail out a failing but socially important firm. The moral hazard problem can then arise as private investors may be more willing to invest in an airline at normal times and less willing to pour more money in to rescue it upon failure.

Jedrychowski (2012) compared the measures used to mitigate the impact of " $9 / 11$ " on the airline industry adopted by the US government and European Commission. The author found that the US government offered substantial short- and long-term support while the European Commission provided only limited supportive measures with a purpose to encourage the industry to seek private restructuring alternatives. Although in the short run some national carriers in Europe failed, in the long run the whole aviation sector has sought to consolidate and returned to profitability (Jedrychowski, 2012). In contrast, in the US, the direct aid helped keep all major US carriers out of bankruptcy in the short run, but in the long run, most airlines still chose to reorganise under Chapter 11. The author thus concluded that considering the historically difficult and cyclical nature of the airline industry, the government should refrain from providing direct financial support. Encouraging airlines to seek reorganisation under either bankruptcy or private measures should be a better option.

If the government refrain from distributing money during the crisis, many airlines will have to seek merger and acquisition (M\&A) to avoid bankruptcy, which will likely result in market concentration in the short-to-medium run (Ma et al., 2020). Some air transport economists have adopted the core theory to look at the unstable nature of the air transport market and argued for a lenient treatment to the increase in air transport concentration (Button, 1996, 2002, 2017; Button and Nijkamp, 1997; Antoniou, 1998). Merger guidelines in many countries allow the approval of an anticompetitive merger if one of the merging parties is failing. This type of antitrust immunity granted constitutes a hidden or covert bailout (Block, 1992).

According to Nyshadham and Raghavan (2001), buyers and sellers trading in a market tend to contract with each other and form groups called coalitions to achieve Pareto efficient outcomes. What the members of the coalitions get is called an allocation. A grand coalition is formed when each buyer and seller can maximise their gains. Such a grand coalition represents the existence of a core. If there is no allocation in the core, an empty core problem arises, which implies that a competitive equilibrium does not exist. Traders may find that they are better off in a sub-market. This condition is labelled by Telser (1987, 1994) as "chaos," meaning that competition is excessive and both buyers and sellers lose.

Telser $(1978,1996)$ claims that in the presence of relatively large fixed costs, avoidable costs, indivisibilities, or network effects, unrestricted competition cannot generate a stable efficient outcome, implying the existence of an empty core. Sjostrom $(1986,1993)$ and Pirrong (1992) suggest that large avoidable costs and finely divisible demand are possible causes for an empty core. Button (1996) notes that given the traffic density effect (that is, the unit costs of providing a service fall as the number of passengers carried on a route increases), operators have the incentive to cut prices to the marginal cost level in the face of the excess capacity. It is a frequent phenomenon that airlines 
cannot cover the full operating costs with such lower prices. The existence of an empty core would mean that Pareto efficiency is not achieved. Understanding the instability of airline industry may have resulted in a lenient antitrust policy towards the M\&A and other consolidation activities in many countries (Button, 2017).

However, some have argued that antitrust laws should not be silent to the consolidation and concentration trend. There is a school of thought arguing that antitrust laws are "more about ethics and equity than efficiency" (Bush, 2010, p.283). Indeed, too much consideration was given to the efficiency argument in the last few decades when antitrust bodies dealt with M\&A cases (Zhang, 2015). Bush (2010) argued that even if efficiency exists, it is not worth much if it is not distributed to consumers. The author warned that using consolidations to save the industry during economic crises may create long-term harm to consumers (Bush, 2010). In addition, consolidations may create a too-big-to-fail situation that may require further consolidations to rescue the industry in the future. Therefore, there has been significant controversy on the lenient treatment towards M\&A even in the period of the economic crisis.

It should be recognised that practically there is no single bailout policy for the airline industry across countries. This has been evident during the COVID-19 pandemic during which the relief measures include tax deferment, waiver of individual taxes, provision of grants and loans, capital injection, etc (see, e.g., Nhamo et al., 2020; European Commission, 2021). The packages of some countries are more generous than those of others. It seems that there are few disputes over the state aid to the aviation industry as a whole, given that this industry is one of the most affected sectors in the pandemic. It is the assistance to the induvial carrier, or the firm-specific bailout that has raised concerns. For example, Ryanair has constantly fought against the state aid given to some flag carriers such as KLM and TAP in the court, arguing that the financial aid for these airlines would reward inefficiency and encourage unfair competition. Some of these challenges have been successful (Chee, 2021). ${ }^{3}$ Although some air transport economists call for a special treatment to the airline industry considering its positive externality and inherent instability, the mainstream view in the law and economic literature contends that the bailout policy for a failing firm should be only used under extreme and specialised circumstances and that each bailout request should be examined on a case-by-case basis, following agreed assessment processes and principles (Posner and Casey, 2015).

The increasing presence of governments in the air transport industry will undoubtedly raise the debates on the issues of airline ownership, air transport deregulation, and environmental sustainability of this sector (Abate et al., 2020). It also gives the governments the chance to exercise politic influence and reshuffle airlines' strategies, thereby potentially changing the competitive field in the post pandemic period (Albers and Rundshagen, 2020). It should be noted that most of the existing studies on airline bailouts do not intend to establish a comprehensive bailout policy analytical framework or guidelines for governments. This research aims to fill this gap. By examining the case of Virgin Australia, we can assess if the Australian government's response to its bailout request is appropriate and what policies need to be developed to help the failing carriers in the future. The findings of this research will shed light on similar cases that might occur in other countries.

\footnotetext{
3 These days, many countries have multiple carriers. The favouritism to one particular carrier, such as the flag carrier that is partly or fully owned by the government, would create an uneven playing field and distort competition in the long run. One example is South African Airways, a state-owned airline that has been constantly receiving bailouts since the 1990s. However, this carrier has been labelled as an overstaffed, inefficient carrier that does not have the incentive to pursue profitability (Tleane, 2020). Therefore, the bailouts were a waste of taxpayers' money with no return.
}

\section{Methodology}

A case study method is used in this research. Case study research is described as qualitative inquiry (Creswell, 1998). Maxwell and Chmiel (2014) claim that case study is the most commonly used method to preserve contextual information in qualitative research, which can provide a broader insight into the research questions. The case study materials regarding Virgin Australia were drawn from its annual financial reports, government reports, and Australian major news websites including news.com.au, theaustralian.com.au, sbs.com.au, and abc. com.au. The opinions of the Aviation Management Major students were also consulted when they were taking the "Aviation Economics" course at the University of Southern Queensland, Australia, in Semester 2, 2020. Most of these students have already had a job in the airline industry. Their opinions were expressed in the course StudyDesk forums as well as the assignments submitted.

The analysis of the case study follows the analytical framework of the public bailout policy developed in Block (1992) and Posner and Casey (2015), which include the following key steps and principles:

i. The presumption against bailout should be firmly established except in rare and specialised circumstances.

ii. Before a public bailout is considered, some key preconditions need to be satisfied.

- A private firm seeking bailout assistance needs to demonstrate that its failure is due to circumstances beyond its control. The wrongdoers should bear the costs. However, the no-fault requirement is not an argument for bailout.

- Public bailouts should not be considered before various forms of private bailouts are attempted first. This may include a Chapter 11 type bankruptcy reorganisation or other efforts in the private markets.

- Before the bailout relief can be considered, it should be expected that the failing firm would collapse without the government assistance.

iii. Even if the above conditions are met, the presumption against bailout should remain until the impact of "not to intervene" is assessed. The public interest test should be applied. The short-run costs and long-run implications due to the loss of the troubled firm needs to be considered.

iv. Even if the bailout seems appropriate, other considerations need to be taken into account including the moral hazard and equity issues, and alternative policies should be explored.

v. Some procedural principles should be followed including public hearing and judicial involvement.

Based on these principals, a typical bailout process can be illustrated with 8 steps in Fig. 1. The bailout request can be rejected at any step if the above principles are not satisfied.

\section{The case study of Virgin Australia}

\subsection{Australian aviation policy and government's attitude towards airline failure}

From the 1950s to 1990, Australia's domestic market was governed by the "two airlines" policy. Two domestic airlines served the routes between state capital cities and some regional routes with identical planes, schedules, and prices with each airline holding approximately 


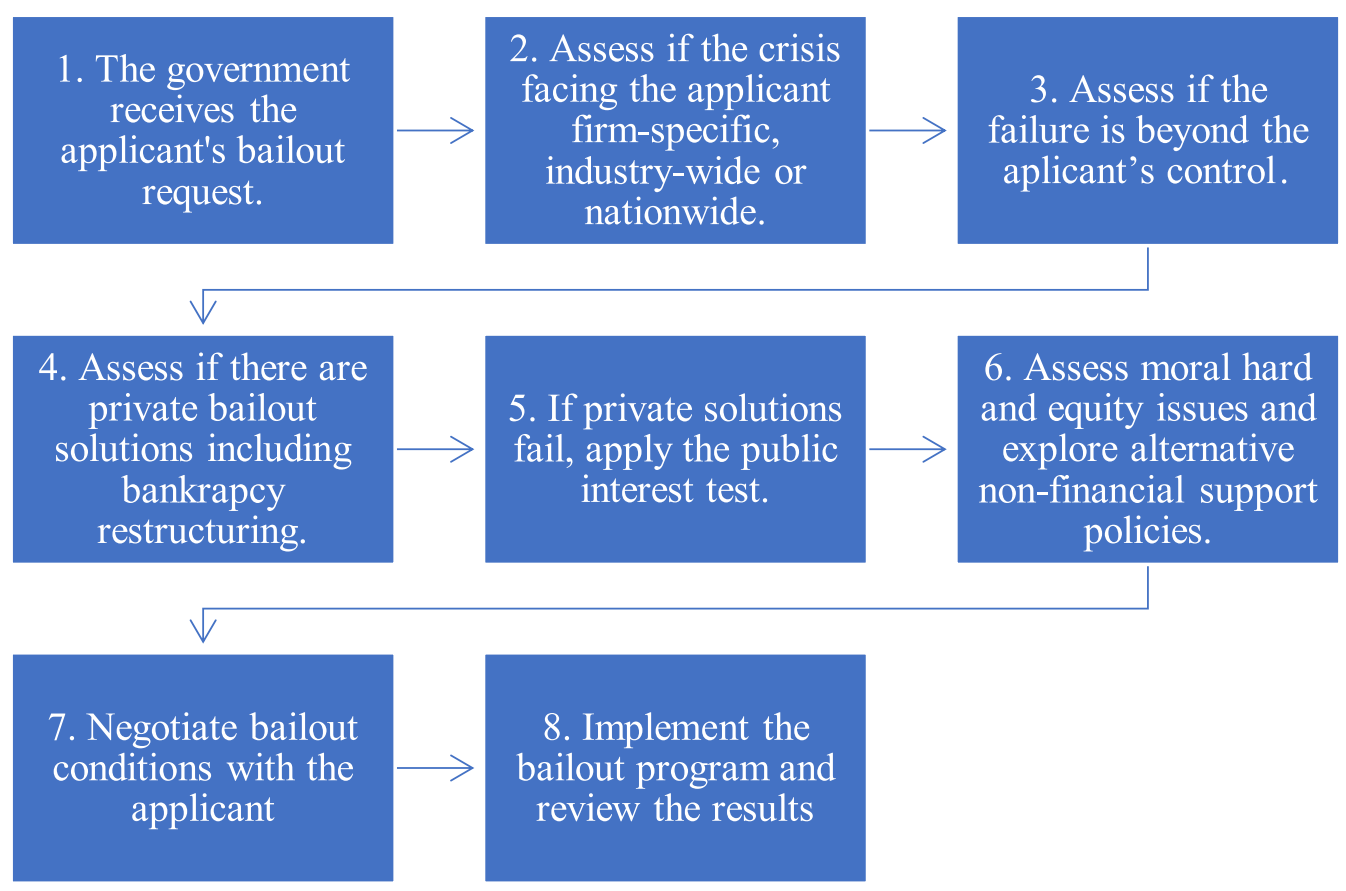

Fig. 1. The bailout process.

50\% of the market share (Quiggin 1997; Zhang et al., 2017). ${ }^{4}$ Douglas (1993) claimed that the Australian domestic market is a natural duopoly, suggesting that the market is not big enough to support more than two carriers. This claim seems to be true in the post-deregulation period as the market continued to be a duopoly, but on a dynamic process with some airlines ceasing operation and being replaced by new ones (Forsyth, 2017). For example, after the two-airline policy was abolished in 1990, Australia's domestic market was largely dominated by Ansett and Qantas in the 1990s. The first low-cost carrier (LCC) Compass I was established in 1990 but quickly failed, as did Compass II. Impulse Airlines was established in 1992 as an independent airline, but was eventually acquired by Qantas in 2001. Virgin Blue entered as an LCC in 2000. With the demise of Ansett in 2001, Virgin Blue had the opportunity to grow rapidly and became a key competitor in the domestic market. The passenger traffic carried by Virgin Blue increased from 3 million in 2002 to about 20 million in 2005. As a response, Qantas launched an LCC subsidiary, Jetstar, in 2003, which is called an airline-within-airlines (AinA) strategy. The launch of Jetstar contained the expansion of Virgin Blue. The joining of another LCC in 2007, Tiger, in the Australian domestic market further limited its growth. An ambitious Game Change Program was implemented in 2010 aiming to transform itself to a full service carrier (FSA) with a new name, Virgin Australia. It followed the AinA strategy by taking over Tiger (rebranded as Tigerair) in 2013 and fully owned this LCC from 2014. However, since the takeover, Virgin Australia has been suffering continuous losses. Both Qantas and Virgin Australia recorded heavy losses in 2013/2014 after they engaged in capacity or price wars (Ma et al., 2019). The loss to Qantas was the largest loss in its history, which prompted its bailout request for a $\$ 2.7$ billion unsecured loan.

The government rejected this request. Instead, the government decided to abolish/ease foreign ownership restrictions imposed on

\footnotetext{
${ }^{4}$ The Australian Standard Geographical Classification (ASGC) Remoteness Structure divides the nation into five categories: major cities, inner regional Australia, outer regional Australia, remote Australia, and very remote Australia (Zhang et al., 2017). The last four categories are broadly called regional area. Regional aviation services refer to the air transport activities between regional areas or between regional areas and capital cities.
}

Qantas to help Qantas. Qantas was privatised in 1994, but this was an incomplete privatisation. The old Qantas Sale Act did not allow any single airline investor to hold more than $25 \%$ of Qantas and any single foreign airline investor to hold more than $35 \%$, capping the total foreign investment at 49\%. In July 2014, the government revised the Act and capped foreign ownership at $49 \%$, with no airline restrictions. Qantas welcomed the foreign ownership relaxation, but said it was not enough. In fact, this was a compromised outcome. Most Australians would not want to see Qantas go bankrupt. Many people even called for renationalising this national icon. Professor Stilwell (2014) put the following argument:

The company needs to be put on a sounder footing, serving the broader needs of the Australian people. In my judgment there is a strong case for returning the airline to public ownership ... There are precedents for renationalisation, e.g. New Zealand's national carrier. To return QANTAS to public ownership would incur the cost of buying out shareholders, but the current low price of those shares makes this affordable. Indeed, the cost could be less than the taxpayer cost of the unemployment benefits and other social service payments that would result from the company's currently proposed downsizing and its possible demise. Government borrowing, at the currently low interest rates, could finance the purchase of the approximately $\$ 2$ billion share capital, which is a relatively small one-off cost compared with other government outlays ...

Fortunately, after restructuring the organisation and taking strict cost control measures, Qantas quickly returned to profitability in 2015 and the following years, but Virgin Australia continued to report losses. The travel restrictions to contain COVID-19 were the final straw for Virgin Australia. The Australian federal government had a request from Virgin for a $\$ 1.4$ billion bailout. However, this request was rejected probably because the federal government believed that the industrywide assistance was enough for the industry to survive. Also it might not be fair to Qantas if only Virgin Australia was given additional assistance. The rejection was also reasonable considering that Virgin Australia had not sought bankruptcy protection according to the preconditions listed in the previous section.

Virgin Australia could not count on its major shareholders, as most of them were airlines who were also in financial difficulty. Singapore 
Airlines, Etihad, Chinese groups Nanshan and HNA, and Richard Branson's Virgin Group jointly held 90\% of Virgin Australia's shares. Many people thus regarded Virgin Australia as a foreign carrier that should not be helped with the Australian taxpayer's money. After the government rejected its final plea for $\$ 200$ million in assistance, Virgin Australia went into voluntary administration (similar to the US Chapter 11) on April 21, 2020, affecting 10,000 staff and 6000 contractors. It was later revealed that this carrier owed more than $\$ 6.8$ billion to more than 12,000 creditors, including employees, banks, aircraft financiers and landlords.

Interestingly, the Queensland state government was keen to save Virgin Australia. It called for the federal government to step in, and expressed its intention to put a $\$ 200$ million bid on the carrier in the form of a direct equity stake, a loan, guarantee or other financial incentives. This is understandable as Virgin Australia was headquartered in Brisbane, Queensland and employed about 5000 Queenslanders. Queensland is different from other states. It has significant tourism assets scattered across the state. Tourism has been the primary industry for many regional towns. Air transport is vitally important in supporting the recovery and growth of the tourism industry and the large number of jobs in this industry. Button (2017) argues that airports, air navigation service providers, airframe and aero-engine manufacturers and global distribution systems rely on airlines to generate the revenues on which they in turn rely. It is also the Queensland government's view that supporting Virgin Australia will not only help retain its head office and crew staff in Queensland, but also grow jobs in the repairs, maintenance and overhaul sector and support both direct and indirect jobs in the tourism industry (Lynch, 2020).

There were about 20 private investors that showed interests in purchasing this carrier. Brookfield Asset Management, Ben Gray's BGH Capital and its partner AustralianSuper, Bain Capital, American Indigo Partners and Cyrus Capital Partners were in the final bidding race for Virgin Australia. Eventually, the Boston-based global investment firm, Bain Capital became the new owner of Virgin Australia with a bid of $\$ 3.5$ billion. The Queensland government and Bain Capital has agreed in principal to keep Virgin Australia's headquarters in Brisbane with the $\$ 200$ million pledge.

Due to the downsizing of fleet size and withdrawal of Tigerair, Virgin Australia's market share fell from 38\% in December 2019 to $24 \%$ in December 2020 (Thomas, 2021). However, under the new ownership of Bain Capital, it managed to increase its domestic share to $28 \%$ in March 2021 . It then planned to return to $80 \%$ of its pre-pandemic capacity by June 2021, though this goal was disrupted when Sydney went into lockdown again in June 2021 and Melbourne in July 2021. However, with many Australian states promising to reopen their borders when vaccination rates reach $80 \%$, Virgin Australia vowed to regain a one-third share of the domestic market by the end of 2021 (Freed, 2021).

The different attitudes of the two levels of government in Australia represent the divided opinions among Australian people towards the fate of Virgin Australia. Following the bailout policy principles established in Block (1992), we attempt to answer the following questions and see if a bailout for Virgin Australia is justified.

\subsection{What have caused the failure of Virgin Australia?}

It is one of the preconditions set by Block (1992) that before government intervention is considered, Virgin Australia needs to show that its failure was purely caused by COVID-19 and other factors beyond its control. If the failure is a result of the long-standing mismanagement, financial help is not justified as the poor management should not be rewarded.

The decisions of rebranding itself as an FSA, acquiring Tigerair and participating in international services have been blamed to have cost the airline too much, resulting in continuous losses. These claims are partly true. Table 1 presents the segment results of Virgin Australia that may help assess the financial performance of the individual segments within
Table 1

Virgin Australia segment results.

\begin{tabular}{lllll}
\hline Revenue and income & 2019 & 2018 & 2017 & 2016 \\
\hline Domestic (\$ million) & 3914.9 & 3682.0 & 3439.6 & 3445.6 \\
International (\$ million) & 1304.8 & 1120.3 & 999.0 & 1016.3 \\
Tigerair (\$ million) & 563.4 & 570.6 & 543.6 & 475.9 \\
Segment EBIT & & & & \\
Domestic (\$ million) & 133.4 & 215.8 & 92.9 & 162.0 \\
International (\$ million) & $(75.6)$ & $(21.7)$ & 0.5 & $(48.8)$ \\
Tigerair (\$ million) & $(45.0)$ & $(39.5)$ & $(24.3)$ & 2.2 \\
\hline
\end{tabular}

Source: Virgin Australia annual financial reports.

the airline group. As can be seen, Virgin Australia actually made money in the domestic market as earnings before interest and taxes (EBIT) recorded positive values in the past few years. However, Tigerair and Virgin Australia International operations reported negative numbers. Given that Tigerair had never been able to make a profit, it was unlikely for Virgin Australia to use it as a strategic asset to fight against Qantas. Some people argue that Virgin Australia should have never bought it in the first place. It has been suggested that the Tiger brand does not have the same value as the Virgin, meaning that Tigerair should be a product of Virgin Australia rather than a separate airline (News.com.au., 2019).

Virgin Australia had a limited international network with flights from Brisbane, Sydney and Melbourne to New Zealand and the South Pacific as well as a few destinations in Asia and North America. However, most of these international routes did not make money. International air transport markets to/from Australia were very competitive with 95 airlines operating scheduled services in early 2020. Unlike Qantas that has established a hub-and-spoke system in Sydney to increase its international passengers at lower operating costs, Virgin Australia has failed to do the same. It has been suggested that Virgin Australia consider closing most of its international services to improve profitability. Overall, although a series of bad management decisions may have led to the failure of Virgin, this does not mean that it has lost all hope to return to profitability, considering its reasonable performance in the domestic market. Therefore, we cannot exclude the bailout option simply based on the mismanagement claim.

\subsection{Are the costs of losing Virgin Australia significant?}

In all cases, a strong public interest test needs to be established for the bailout to go ahead as noted in the methodology section. It is not appropriate if the bailout just benefits Virgin Australia's debtors, shareholders, management and employees. The benefits to the wider community need to be identified.

From the consumers' perspective, keeping Virgin Australia alive is in their interest in that having two airlines promotes competition. It took more than ten years for Virgin Australia to become an effective challenger to Qantas. In fact, the Qantas Group still holds two thirds of the market share and is dominant on many routes. With the demise of Air Berlin in 2017, significant anticompetitive concerns have been raised in Grosche et al. (2020) as the Lufthansa Group became more dominant in the German market. In the Australian domestic market, if Virgin fails, there will be airlines to enter in the long run, but it will take a long time for the new carrier to be an effective challenger. So for a significant amount of time, Qantas may enjoy a monopoly status. The likely detrimental effect can be seen from the pricing dynamics between Qantas and Virgin Australia. Ma et al. (2019) reported that Qantas and Virgin closely matched each other's prices over years as shown in Fig. 2. This figure also shows that Jetstar charged a higher price than Tigerair before 2016, implying that Qantas used Jetstar as a fighting brand against other LCCs to retrain the Qantas Group's 65\% market share goal. This suggests that despite Qantas Group's dominant market share, it did not command price leadership in the presence of Virgin Australia. Instead, Qantas and Jetstar adjusted their prices significantly in response to Virgin's pricing dynamics (Zhang et al., 2018). 


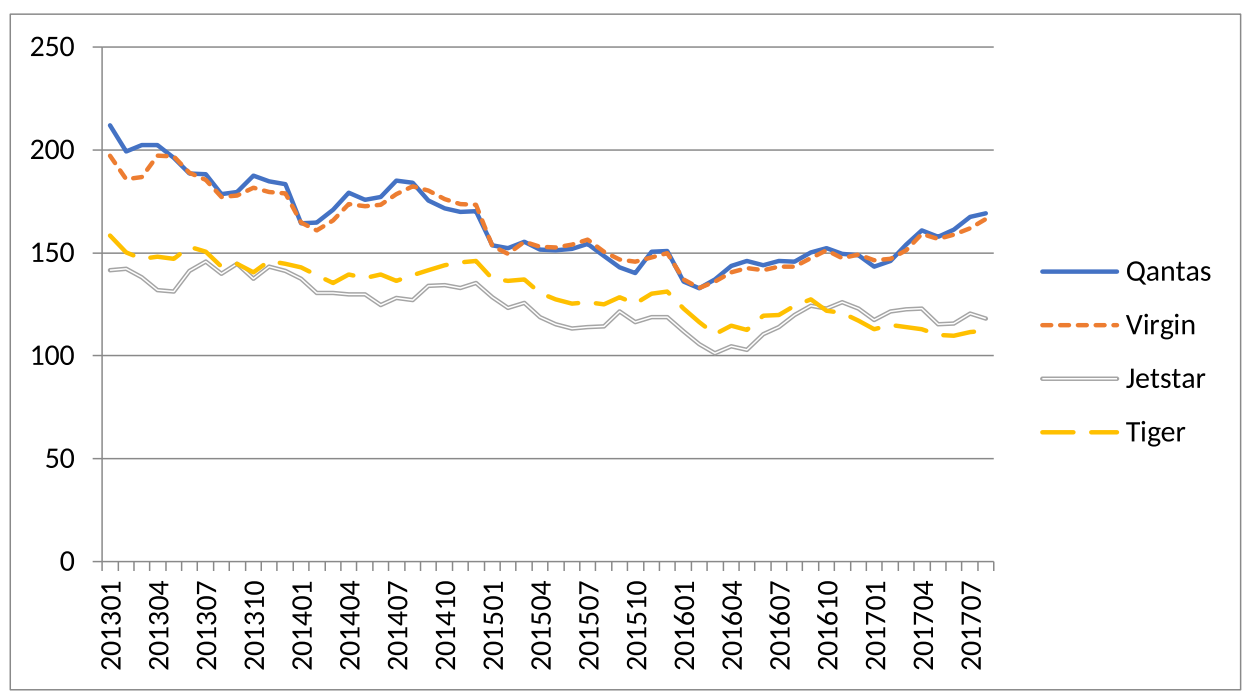

Fig. 2. Monthly average airfares between Qantas and Virgin Groups

Source: Adapted from Ma et al. (2019).

In the domestic market, Qantas' AinA strategy has been quite successful. In August 2017, of Australia's top 144 domestic origindestination markets in terms of passenger traffic volume, Qantas and Jetstar were simultaneously present in 95 of these markets, while Virgin and Tigerair were both present in 75 markets (Zhang et al., 2021). All four carriers were competing in 71 of the 144 markets. These observations suggest that Virgin Australia was an effective competitor and constraint to Qantas in suppressing domestic airfares. Its wide presence is unlikely to be replaced by a new carrier any time soon. The AinA strategy adopted by Qantas has successfully defended its 65\% market share bottom-line and put Virgin Australia in financial stress. It is expected that this strategy would also make it difficult for any new entrants to succeed if Virgin Australia were to exit.

Regional Australia benefits from the competition. Ma et al. (2019) note that the occurrence of price wars between Qantas and Virgin Australia could be nationwide, including routes to/from regional areas. For example, in 2017, Qantas cut airfares across the country including flights to/from Rockhampton as part of their "Fly Away Sale". The price cuts were immediately matched by Virgin Australia. Regional Australia accounts for one third of Australia's population and contributes significantly to the national economy (Zhang et al., 2017). In the last decade or so, many regional areas in Australia have become increasingly dependent on the tourism and mining industries, which rely heavily on reliable and affordable air services. Virgin Australia provides essential services into some well-known tourism destinations in Queensland including Cairns, Gold Coast, Airline Beach, Hamilton Island, Sunshine Coast, Hervey Bay, Mackay and Townsville. In recent years, there have been increasing complaints about the high regional route airfare by Australian regional residents, which prompted a Senate inquiry into the air services in regional, rural and remote Australia (The Senate, 2019). A loss of a major player like Virgin Australia could result in an even higher travel cost burden for regional residents. Abate et al. (2020) argue that the government needs to balance its obligations of maintaining basic and essential connectivity against the use of private capital and expertise to save the failing carriers.

Both monopoly power and the lack of sufficient private provision of air services (owing to its positive external effects) are a kind of market failure, which may justify government intervention. However, it is understood that Australia has done away with the idea of nationalisation for many years. ${ }^{5}$ The government did not bail out Ansett in 2001, but at that time, Virgin Blue had been in operation for one year as an LCC and was able to fill the void left by Ansett, eventually forcing Qantas to launch its own LCC, Jetstar, in 2003. However, the business travel market was still a monopoly until Virgin shifted to the FSA model, which represented a welfare loss to business travellers for a long time. Sciberras (2020) argues that it took Virgin Blue more than ten years to build the necessary infrastructure and products such as their frequent flyer program and business lounges to allow it to effectively compete against Qantas in the business and corporate market. This transformation required a huge investment, which contributed partly to Virgin Australia's losses in the last seven years.

\subsection{Are there alternative solutions except for public bailouts?}

The government consistently refused to bail out Qantas in 2014. The alternative measure, i.e., relaxing foreign-ownership restriction were used to help Qantas receive fund injections from many interested investors around the world. However, when COVID-19 hit the world in 2020, the impact was across the board and far longer and deeper than any other exogenous shock. It was not known if the private market could provide a solution that helped avoid a Qantas monopoly.

Fortunately, the long list of potential bidders indicated that Virgin Australia was a commercial proposition and the government intervention could be avoided and kept at a minimum level. The eventual sale of Virgin Australia to Bain Capital was great news to consumers, airline employees and the governments at both levels. However, some 3000 jobs had to go, mainly due to the indefinite suspension of the long-haul international routes, the cessation of its LCC brand Tigerair and suspension of some regional routes. This outcome suggests that Australia's air transport sector is resilient and adaptable, and that the private market can provide a solution to a failing airline in this pandemic crisis. Therefore, it seems that the government should not rush to save an airline by providing direct aid in the first instance. Airlines can be

\footnotetext{
5 Nationalisation of airlines again was called for to help airlines to survive the impact of the pandemic in other countries. However, this has never been an option for Virgin Australia that is not regarded as a flag carrier or national icon.
} 
allowed to restructure and downsize to adjust themselves to the new normal. Any government assistance including the $\$ 200$ million pledge to Virgin Australia should not delay the needed restructuring in the industry. ${ }^{6}$ In fact, even with government assistance, job losses are still unavoidable if Virgin Australia wants to return to profitability. Therefore, preserving jobs alone is not a sufficient excuse to bail out the carrier, especially when the opportunity cost of the bailout fund is considered.

Does this imply that a hands-off approach should be adopted by the government? The answer is certainly no. The government should first consider the causes of the failure and assess if there are solutions from the private market. Virgin Australia could generate substantial revenue from the domestic market. However, until October 2020, domestic borders remained closed between some states. This has worsened the financial positions of both Qantas and Virgin Australia. Lifting the travel restrictions between states was something that the federal government could do to assist the airline industry. In addition, the government can simplify and expedite the insolvency process for failing companies by adopting some elements of the US Chapter 11 bankruptcy regime. Currently a failing company will be handed over to an external administrator and a shift to the debtor in possession regime will give financially distressed companies more flexibility to restructure.

If no private sale deal could be reached in the Virgin Australia case, should the government provide direct financial support? There is no easy answer. People may argue that any financial aid will create unfairness that would benefit the creditors and shareholders of a mismanaged business whose collapse may not have serious macroeconomic consequences like a big financial firm. However, considering Virgin Australia's relatively strong performance in the domestic market, its significance to consumers and regional communities, and the low confidence towards airline industry from the lenders and investors in the pandemic, individualised rescue programs could be considered with some conditions including the repayment of the taxpayer money at a later time and some political objectives such as servicing some thin regional routes (Albers and Rundshagen, 2020). There is risk, as the government assistance required by Virgin Australia is not a small amount, which may force the government to cut expenditures on other projects. However, compared with the costs of losing an effective competitor, it may be still relatively small and most likely it can be a one-off cost if the COVID-19 pandemic can be contained and economic conditions improve in the near future. However, the bailout decision should not be taken in a rush. A public hearing might be needed to have the voices of different stakeholders heard.

\section{Conclusion}

The impact of COVID-19 on air transport is unprecedented and the future of many airlines remain uncertain. Governments around the world have responded quickly to cushion the financial impact by offering direct wage subsidies, tax relief, loans, etc. This paper presents a case study on whether the Australian government should save Virgin Australia. The outcome suggests that the private market can provide a solution without government intervention for the case of Virgin Australia, which is consistent with the widely held view that the government should refrain from giving direct financial aid to a failing firm. However, our analysis also shows that if the private sale deal were not realised, the cost would be huge in terms of (for example) the interests of Australian consumers and regional communities. A minimum level of assistance with conditions can be considered to restore competition in Australian domestic market and maintain air transport connectivity for regional areas. These conditions can include high interest rates and

\footnotetext{
${ }^{6}$ Therefore, if needed, the most appropriate timing for the government intervention might be after private solutions including bankruptcy reorganisation, have been sought and failed.
}

other penalties to bring some pains for creditors and shareholders (Posner and Casey, 2015). Our analysis has shown that Virgin engaged in some risky investment activities in the last ten years. These conditions will deter the airline from taking on excessive risk in the future.

Traditionally the term "too big to fail" is linked to the banking sector where a big financial firm would not be allowed to fail. However, research has shown that there is no evidence that a failure of one financial institution could collapse the whole financial system and the economy (Moosa, 2010). Similarly, the consequence of the failure of an airline is at best short run and limited, particularly in a market where entry and exit barriers have been largely lifted. In fact, it is difficult to apply the "too big to fail" doctrine to Virgin Australia that only commanded $38 \%$ of the market share before the onset of Covid-19. It is also noticed that although the impact of Covid-19 pandemic on the economy and air transport may exceed that of any previous crisis, the global share markets have performed strongly since mid-2020, suggesting that investors are confident about the economic recovery ahead. In the meantime, during the pandemic, people have had an increased desire to travel, especially the desire to visit friends and families (Krishnan et al., 2021). This implies that there would be investors who are willing to take the risk and grip opportunities to invest in airlines. Therefore, private solutions should be sought first before the taxpayer money is used.

It is always difficult to make a bailout decision. As noted by Block (1992), governments should treat bailouts as extraordinary events, which should not be lightly undertaken. Government interventions can increase political influences in the organisation which may not benefit their long-term survival (Habersang et al., 2019). The case of Virgin Australia presented in this paper further shows the significant role played by the bankruptcy protection in helping failing firms to reorganise and restructure, which should be considered as the first solution. A detailed economic analysis regarding the cost and benefit is certainly needed to establish a strong public interest argument before the bailout decision is made. Other considerations such as the effects of moral hazard and rewarding mismanagement might be equally important. As the literature on airline bailout guidelines remains scarce, researchers can examine more bailout cases during the COVID-19 pandemic crisis to establish a strong analytical framework to inform the government's bailout policy towards the air transport sector.

Finally, we should point out that except for their key role in transporting essential goods and medical supplies, the importance of Qantas and Virgin Australia to the economy has declined since the country has closed its border to other countries, as Australia has taken an elimination strategy in the fight against COVID-19 (Tisdall et al., 2021). Its international border remained closed in September 2021. Many Australian states and territories also closed their borders to passengers from another state where community transmission was not controlled. Qantas and Virgin Australia are not expected to resume their international flights by the end of 2021. The border closures may have affected the bailout policy as restoring passenger travel is certainly not a priority agenda of the government. We cannot exclude the possibility that the Australian federal government may see that the border closures provide a time window for Virgin Australia to seek private solutions and thus refrain from giving a hand in this first instance. ${ }^{7}$

\section{Author statement}

Yahua Zhang: Writing-Original draft, Methodology, Formal analysis. Anming Zhang: Validation, Writing- Review \& Editing.

\section{Acknowledgement}

We would like to thank two anonymous reviewers' helpful comments that have improved the paper markedly. Partial financial support from

\footnotetext{
${ }^{7}$ We thank one anonymous reviewer for raising this point.
} 
the Social Sciences and Humanities Research Council of Canada (SSHRC) is gratefully acknowledged.

\section{References}

Abate, M., Christidis, P., Purwanto, A.J., 2020. Government support to airlines in the aftermath of the COVID-19 pandemic. J. Air Transport. Manag. 89, 101931.

Albers, S., Rundshagen, V., 2020. European airlines' strategic responses to the COVID-19 pandemic (January-May, 2020). J. Air Transport. Manag. 87, 101863.

Antoniou, A., 1998. The status of the core in the airline industry: the case of the European market. Manag. Decis. Econ. 19 (1), 43-54.

Azgad-Tromer, S., 2017. Too important to fail: bankruptcy versus bailout of socially important non-financial institutions. Harvard Business Law Review 7 (1), 159-186.

Backx, M., Carney, M., Gedajlovic, E., 2002. Public, private and mixed ownership and the performance of international airlines. J. Air Transport. Manag. 8 (4), 213-220.

Block, C.D., 1992. Overt and covert bailouts: developing a public bailout policy. Indiana Law J. 67, 951.

Block, C.D., 2010. Measuring the true cost of government bailout. Washington University Law Review 88 (1), 149-228.

Bush, D., 2010. Too big to bail: the role of Antitrust in Distressed Industries. Antitrust Law J. 77, 277-312.

Button, K., 1996. Liberalizing European aviation: is there an empty core problem? J. Transport Econ. Pol. 30, 275-291.

Button, K., 2002. Empty cores in airline market. In: Paper Presented at the 5th Hamburg Aviation Conference, 14-15 February 2002.

Button, K., 2017. Market instability. In: Finger, M., Button, K. (Eds.), Air Transport Liberalization. Ch15. Edward Elgar Publishing, pp. 284-312.

Button, K., Lall, S., 1999. The economics of being an airport hub city. Res. Transport. Econ. 5, 75-105.

Button, K., Nijkamp, P., 1997. Network Industries, Economic Stability and Spatial Integration. Tinbergen Institute Discussion Papers 97-047/3. Tinbergen Institute.

Chee, F.Y., 2021. Ryanair Gets Rare Wins in EU Court over State Aid for KLM and TAP. Reuters. Available at. https://www.reuters.com/business/aerospace-defense/eucourt-backs-ryanair-challenge-klm-tap-state-aid-2021-05-19/.

Christidis, P., Christodoulou, A., 2020. The predictive capacity of air travel patterns during the global spread of the COVID-19 pandemic: risk, uncertainty and randomness. Int. J. Environ. Res. Publ. Health 17, 3356.

Creswell, J.W., 1998. Qualitative Inquiry and Research Design: Choosing Among the Five Traditions. Sage, Thousand Oaks, CA.

Douglas, E.J., 1993. Airline Competition and Strategy in Australia. School of Business Discussion Paper No 41. Bond University, Gold Coast, QLD.

European Commission, 2021. State Aid: Commission Approves $€ 525.3$ Million German Aid in Favour of Airline Condor in Context of Coronavirus Outbreak. Press release available at. https://ec.europa.eu/commission/presscorner/detail/en/IP_21_3909.

Forsyth, P., 2017. Australia - a reluctant liberalizer. In: Finger, M., Button, K. (Eds.), Air Transport Liberalization. Ch4. Edward Elgar Publishing, pp. 51-68.

Freed, J., 2021. Virgin Australia Readies for a Domestic Recovery by Adding 9 Boeing $737 \mathrm{~s}$ to its Fleet. Reuters.

Fu, X., Oum, T.H., Zhang, A., 2010. Air transport liberalization and its impacts on airline competition and air passenger traffic. Transport. J. 49 (4), 24-41.

Gilbert, M., Pullano, G., Pinotti, F., Valdano, E., Poletto, C., Boelle, P., Colizza, V., 2020. Preparedness and vulnerability of African countries against importations of COVID19: a modelling study. Lancet 395, 871-877, 10227.

Grosche, T., Klophaus, R., Seredyński, A., 2020. Market concentration in German air transport before and after the Air Berlin bankruptcy. Transport Pol. 94, 78-88.

Habersang, S., Küberling-Jost, J., Reihlen, M., Seckler, C., 2019. A process perspective on organizational failure: a qualitative meta-analysis. J. Manag. Stud. 56 (1), 19-56.

Jedrychowski, E., 2012. The post-September 11 U.S. and European airline industries: navigating through the bailouts, bankruptcies, liquidations and mergers. Conn. J. Int. Law 28 (1), 177-198.

Krishnan, V., Rivas, D., Saxon, S., 2021. A Travel Boom Is Looming. But Is the Industry Ready? Mckinsey \& Company. July 27, 2021.

Lynch, L., 2020. Queensland government to bid for Virgin Australia airline. The Age, Retrieved May 26, 2020 from. https://www.theage.com.au/politics/queensland/ queensland-government-to-bid-for-virgin-australia-airline-20200513-p54sny.html.

Ma, W., Wang, Q., Yang, H., Zhang, Y., 2019. An analysis of price competition and price wars in Australia's domestic airline market. Transport Pol. 81, 163-172.

Ma, W., Wang, Q., Yang, H., Zhang, Y., 2020. Is multimarket contact an antitrust concern? A case of China's airline market. Transport. Res. Pol. Pract. 132, 515-526.

Maxwell, J., Chmiel, M., 2014. Notes toward a theory of qualitative data analysis. In: Flick, U. (Ed.), The SAGE Handbook of Qualitative Data Analysis. SAGE Publications, London, pp. 21-34.

Moosa, I., 2010. The myth of too big to fail. J. Bank. Regul. 11 (4), 319-333.

Newscomau, 2019. Tigerair a 'drag' on Virgin Australia's Bottomline. Retreived May 29, 2020 from. https://www.news.com.au/travel/travel-advice/flights/budget-carri er-tigerair-could-be-shut-down-by-virgin-australia-says-major-investor/news-st ory/ae5c6fa358dc20c1db6b3188b890eeeb.

Nhamo, G., Dube, K., Chikodzi, D., 2020. COVID-19 and implications for the aviation sector: a global perspective. In: Counting the Cost of COVID-19 on the Global Tourism Industry. Springer, Cham, pp. 89-107.

Nyshadham, E.A., Raghavan, S., 2001. The failure of electronic markets in the air cargo industry: a core theory explanation. Electron. Mark. 11 (4), 246-249.

April 6 Pearce, B., 2018. The Economics of Airline Financial Performance and Wider Economic Benefits. Retrieved May 20, 2020, from. https://www.iata.org/en/iatarepository/publications/economic-reports/the-economics-of-airline-financial-pe rformance-wider-benefits/.

Pirrong, S.C., 1992. An application of core theory to the analysis of ocean shipping markets. J. Law Econ. 35, 89-131.

Posner, E.A., Casey, A.J., 2015. A framework for bailout regulation. Notre Dame Law Rev. 91, 479-536.

Pullano, G., Pinotti, F., Valdano, E., Boelle, P., Poletto, C., Colizza, V., 2020. Novel coronavirus (2019-nCoV) early-stage importation risk to Europe, January 2020. Euro Surveill. 25 (4) pii=2000057.

Quiggin, J., 1997. Evaluating airline deregulation in Australia. Aust. Econ. Rev. 30 (1), 45-56.

Sciberras, D., 2020. OK, it Is Time to Talk about Virgin Australia. Point Hacks. Retrieved May 30, 2020 from. https://www.pointhacks.com.au/virgin-australia-editors-view/.

Sjostrom, W., 1986. Collusion in ocean shipping: a test of monopoly and empty core models. J. Polit. Econ. 97, 1160-1179.

Sjostrom, W., 1993. Antitrust immunity for shipping conferences: an empty core approach. Antitrust Bull. 38, 419-423.

Stilwell, F., 2014. Submission to the QANTAS Inquiry Established by the Federal Government, Rural and Regional Affairs and Transport References Committee. Retrieved May 252020 from. https://www.aph.gov.au/DocumentStore.ashx?id $=833 \mathrm{ae} 4 \mathrm{e} 7-8 \mathrm{e} 8 \mathrm{f}-4 \mathrm{ef5}-9 \mathrm{~d} 3 \mathrm{f}-\mathrm{d} 82 \mathrm{~d} 3733 \mathrm{db} 8 \mathrm{f} \&$ subId $=205823$.

Sun, X., Wandelt, S., Zhang, A., 2020. How did COVID-19 impact air transportation? A first peek through the lens of complex networks. J. Air Transport. Manag. 89, 101928.

Telser, L.G., 1978. Economic Theory and the Core. University of Chicago Press, Chicago.

Telser, L.G., 1987. A Theory of Efficient Cooperation and Competition. Cambridge University Press, Cambridge.

Telser, L.G., 1994. The usefulness of core theory in economics. J. Econ. Perspect. 8 (2), 151-164.

Telser, L.G., 1996. Competition and the core. J. Polit. Econ. 104 (1), 85-107.

The Senate, 2019. Operation, Regulation and Funding of Air Route Service Delivery to Rural, Regional and Remote Communities. Rural and Regional Affairs and Transport References Committee. The Commonwealth of Australia.

Thomas, G., 2021. Virgin Australia Market Share Surges. Airline Ratings. Available at. https://www.airlineratings.com/news/virgin-australia-market-share-surges/.

Tisdall, L., Zhang, Y., 2020. Preparing for 'COVID-27': lessons in management focus-An Australian general aviation perspective. J. Air Transport. Manag. 89, 101922.

Tisdall, L., Zhang, Y., Zhang, A., 2021. COVID-19 impacts on general aviation-comparative experiences, governmental responses and policy imperatives. Transport Pol. 110, 273-280.

Tleane, K., 2020. State-owned enterprise bailouts on economic growth: a case on South African Airways. In: International Conference on Public Administration and Development Alternative (IPADA).

Yu, H., Zhang, Y., Zhang, A., Wang, K., Cui, Q., 2019. A comparative study of airline efficiency in China and India: a dynamic network DEA approach. Res. Transport. Econ. 76, 100746.

Zhang, A., 2012. Airport improvement fees, benefit spillovers, and land value capture mechanisms. Ch. 13. In: Ingram, G.K., Hong, Y.-H. (Eds.), Value Capture and Land Policies. Lincoln Institute of Land Policy, Cambridge, MA, pp. 323-348.

Zhang, Y., 2015. Merger between airlines in financial distress: does the merger save them? Compet. Regul. Netw. Ind. 16 (1), 66-81.

Zhang, Y., Findlay, C., 2010. Air transport liberalization. In: Ghani, E. (Ed.), The Service Revolution in South Asia. Oxford University Press.

Zhang, A., Zhang, Y., 2018. Airline economics and finance. Ch. 11. In: Graham, A., Halpern, N. (Eds.), The Routledge Companion to Air Transport Management. Routledge, pp. 171-188.

Zhang, Y., Wang, K., Fu, X., 2017. Air transport services in regional Australia: demand pattern, frequency choice and airport entry. Transport. Res. Pol. Pract. 103, $472-489$.

Zhang, G., Law, C.H., Zhang, Y., Yang, H., 2021. Price discrimination and yield management in the airline industry. In: International encyclopedia of transportation, 1. Elsevier, Amsterdam, Netherlands, pp. 404-408.

Zhang, Y., Sampaio, B., Fu, X., Huang, Z., 2018. Pricing dynamics between airline groups with dual-brand services: the case of the Australian domestic market. Transport. Res. Pol. Pract. 112, 46-59.

Zhang, Y., Zhang, A., Wang, J., 2020. Exploring the roles of high-speed train, air and coach services in the spread of Covid-19 in China. Transport Pol. 94, 34-42. 